\title{
Cerebral Alveolar Echinococcosis Concomitant with Liver and Lung Lesions in a Young Adult Patient: Case Report and Literature Review
}

\author{
Genç Yetişkinde Karaciğer ve Akciğer Kitlelerinin Eşlik Ettiği Serebral Alveolar \\ Ekinokokkoz: Olgu Sunumu ve Literatürün Gözden Geçirilmesi
}

\author{
Osman Ersegun Batçık², Ahmet Öğrenci ${ }^{3}$, Orkun Koban4, Murat Şakir Ekşii', Turgay Bilge ${ }^{5}$ \\ 'Department of Orthopedic Surgery, University of California at San Francisco, San Francisco, USA \\ 2Department of Neurosurgery, Rize Recep Tayyip Erdoğan University School of Medicine, Rize, Turkey \\ ${ }^{3}$ Clinic of Neurosurgery, Batman State Hospital, Batman, Turkey \\ ${ }^{4}$ Clinic of Neurosurgery, Kurtkoy Ersoy Hospital, İstanbul, Turkey \\ ${ }^{5}$ Clinic of Neurosurgery, Private Practice, İstanbul, Turkey
}

\section{ABSTRACT}

We present the case of a 25 -year-old male harboring multiple brain lesions mimicking tumor metastasis that were revealed to be caused by Echinococcus multilocularis. Cerebral echinococcosis with multiple lesions is rare and might be confused with a brain abscess, tuberculoma, or metastatic tumor disease. Brain magnetic resonance imaging and serological studies are helpful in the differential diagnosis. In case of $E$. multilocularis, cerebral invasion is the late stage of the disease that necessitates an aggressive treatment protocol.

Keywords: Cerebral echinococcosis, metastasis, albendazole

Received: 29.11.2015 Accepted: 10.06.2016

\section{Öz}

Bu olgu sunumunda, metaztatik beyin tümörünü taklit eden, çoklu beyin lezyonları olan 25 yaşında erkek bir hastadan bahsedilmektedir. Çoklu beyin lezyonları olan serebral ekinokokkoz nadirdir ve beyin absesi, tüberküloma ile metaztatik beyin tümörü ayırıcı tanılar içinde yer alır. Beyin manyetik rezonans görüntüleme ve serolojik çalışmalar ile ayrıcı tanı mümkündür. E. multilocularis hastalığında beyin invazyonu hastalığın geç evresinde gerçekleşir ve bu aşamada agresif tedaviler uygulanmalıdır.

Anahtar Kelimeler: Serebral ekinokokkoz, metastaz, albendazol

Geliş Tarihi: 29.11.2015 Kabul Tarihi: 10.06.2016

\section{INTRODUCTION}

Larval forms of the taeniid cestode of Echinococcus cause human echinococcosis. There are six species of Echinococcus: E. granulosus, E. multilocularis, E. vogeli, E. oligarthrus, E. shiquicus, and E. felidis. E. granulosus is the most common species in humans (1). E. multilocularis was first defined in the 1950s (2). E. multilocularis is a tapeworm that is $1.2-4.5 \mathrm{~mm}$ in size and causes alveolar echinococcosis $(3,4)$. E. multilocularis has an exogenous budding pattern, invades surrounding tissues, and completes its life cycle by transmission between two different hosts $(1,4)$.
We present the case of a 25-year-old male harboring multiple brain lesions mimicking tumor metastasis that were revealed to be caused by $E$. multilocularis.

\section{CASE REPORT}

A 25-year-old male visited an outpatient clinic due to dizziness, headache, and seizure. He was a seasonal worker. His motor strength was normal. He had bilateral horizontal nystagmus, and his Romberg test result was positive. His Babinski reflex was extensor bilaterally. Brain contrast-enhanced T1-weighted magnetic resonance imaging (MRI)

Address for Correspondence / Yazışma Adresi: Dr. Murat Şakir Ekşi E.mail: muratsakireksi@gmail.com DOI: 10.5152/tpd.2016.4624

CCopyright 2016 Turkish Society for Parasitology - Available online at www.tparazitolderg.org

CTelif hakkı 2016 Türkiye Parazitoloji Derneği - Makale metnine www.tparazitolderg.org web sayfasından ulaşılabilir. 

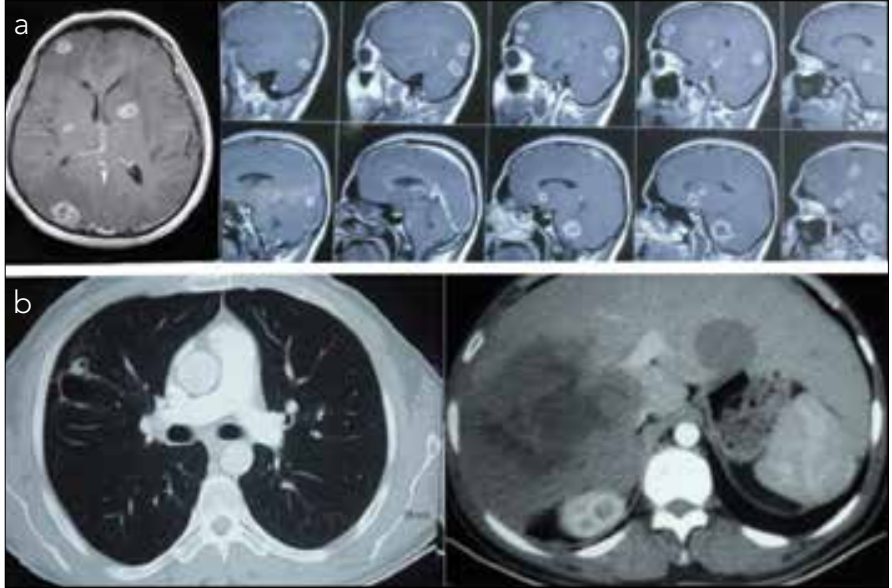

Figure 1. a-b. Contrast-enhanced multiple brain lesions are supra- and infratentorially present on T1-weighted MRI (a); some other lesions are observed in the right lung and in the liver (b)



Figure 2. a-c. One of the multiple lesions in the brain was excised $(a, b)$; immediate post-operative brain MRI depicts en bloc resection of the lesion that was present in the right occipital lobe (c)

depicted 19 lesions with irregular borders and peripheral ring enhancement. Four lesions were comparatively large: one each in the right occipital lobe, right frontal lobe, left parietal lobe, and left cerebellum (Figure 1a). Tumor metastasis was the initial diagnosis. To find the primary origin, chest and abdominal computed tomography (CT) scans were performed, which revealed diffusely disseminated lesions in the liver and one lesion in the right lung (Figure 1b). His laboratory test results were normal, except his erythrocyte sedimentation rate, which was $80 \mathrm{~mm} / \mathrm{h}$. With this finding and the fact that he originate from an area endemic to echinococcosis, parasitic infestation became the differential diagnosis. The hemagglutination test for echinococcosis was positive. To relieve the mass effect and edema in the brain, the lesion in the right occipital lobe was excised en bloc (Figure 2a-c). The lesion had smooth borders with the brain parenchyma. The pathology was compatible with Echinococcus multilocularis. The patient was referred to an infectious disease specialist with albendazole $2 \times 400 \mathrm{mg}$. However, the lesions did not respond to albendazole therapy. Praziquantel was added to the chemotherapeutic regimen. The patient's condition progressively deteriorated, and he died one year after the surgery.

\section{DISCUSSION}

Cerebral echinococcosis is observed in 0.5-3\% of patients with echinococcosis and is mostly seen in children and young adults. It comprises $3-4 \%$ of all intracranial lesions $(5,6)$. There is a male preponderance, with a male: female ratio of $1.5: 1$. The most common species diagnosed in the brain are $E$. granulosus (97.1\%) and E. multilocularis (2.9\%) (6).

A supratentorial location, particularly in the parietal lobe, is the most common location for cerebral echinococcosis. The posterior cranial fossa and ventricles are rare locations (5-8). In the current case, there were multiple brain lesions caused by E. multilocularis not only in the supratentorial area but almost everywhere inside the cranium. Presentation in multiple locations is quite rare (9). Underlying mechanisms for multiple cerebral lesions of echinococcosis have been proposed to be caused by the rupture of a solitary cyst or embolization of cyst particles from ruptured cysts inside remote organs $(5,7,8,10)$. Concomitant organ infestation is seen in $18 \%$ of patients with cerebral echinococcosis (6).

Clinical signs and symptoms in patients with cerebral echinococcosis are headache, increased intracranial pressure, papilledema (63\%), optic atrophy, nausea, vomiting, cranial nerve palsy, seizure (24\%), focal neurological findings, cognitive deficit, ataxia, speech disorder, visual disturbances, head swelling, difficulty in swallowing, and chorea $(6,11-16)$.

In the differential diagnoses, tumor metastasis, tuberculoma, and abscess formation are present. Metastatic tumors harbor enhanced nodules. Peripheral edema around the ring enhancement is seen in abscesses. In such circumstances, concomitant clinical and laboratory findings might be present with the abscess. On T2-weighted MRI, the abscess is hyperintense, whereas alveolar echinococcosis is hypointense. A tuberculoma has nodular homogenous enhancement $(5,16-18)$. Cerebral echinococcosis with multiple lesions has similar radiological findings. Calcification on a CT scan has been reported $(6,9,16)$. Contrast enhancement and pericystic edema result from recurrences of echinococcosis, which lead to inflammatory reactions in the infection zone $(5,6,16)$. In alveolar echinococcosis, the inflammatory reaction forms a capsule around the lesion that is as hard as the cartilage tissue (16). Human leucocyte antigen (HLA) B8 positivity is associated with metastasis of E. multilocularis (19). Due to difficulties in diagnosis, a definitive diagnosis can be made via specimen analysis (6). Our patient had concomitant lung and liver disease, which may have led to the embolization of the infection to the supra- and infratentorial brain.

The recurrence rates of cerebral echinococcosis are $13 \%$ and $4 \%$ after the surgery-only and surgery with chemotherapy approaches, respectively. The mortality rate is $10 \%$ for cerebral echinococcosis. However, the mortality rate is higher in patients with multiple lesions than in those with a single lesion (13 vs. 7\%) (6). Cerebral metastasis is observed in only $1 \%$ of patients with alveolar echinococcosis and is considered as the terminal stage of the disease (16). The aim of surgery is to excise symptomatic lesion(s) with a pronounced mass effect.

Albendazole and mebendazole are two anthelmintic drugs, yet albendazole is preferable due to its better pharmacokinetic properties. Routine complete blood count and liver function studies should be conducted during follow-up with albendazole (16). Further studies are necessary to develop better treatment 
protocols in patients with cerebral echinococcosis, particularly those with multiple brain lesions and who are resistant to surgery and chemotherapy.

\section{CONCLUSION}

Cerebral echinococcosis with multiple brain lesions is rare and can be confused with a brain abscess, tuberculoma, or metastatic tumor disease. Brain MRI and serological studies are helpful in the differential diagnosis. Surgery is indicated whenever the intracranial mass effect and/or edema are observed in symptomatic patients. In case of E. multilocularis, cerebral invasion indicates the late stage of the disease, necessitating aggressive treatment protocols that should be analyzed in further clinical and laboratory studies.

Informed Consent: The informed consent could not be retrieved due to the decease of the patient and discontinuity of follow-up.

Peer-review: Externally peer-reviewed.

Author Contributions: Concept - M.Ş.E., A.Ö., O.K., O.E.B.; Design M.Ş.E., A.Ö.; Supervision - A.Ö., T.B.; Funding - A.Ö., O.E.B., T.B.; Materials - O.K., O.E.B., T.B.; Data Collection and/or Processing - A.Ö., M.Ş.E.; Analysis and/or Interpretation - M.Ş.E., A.Ö., O.E.B.; Literature Review - M.Ş.E.; Writing - O.E.B., M.Ş.E., A.Ö., O.K.; Critical Review - T.B.

Conflict of Interest: No conflict of interest was declared by the authors.

Financial Disclosure: Murat Sakir Eksi, M.D. was supported by a grant from Tubitak (The Scientific and Technological Research Council of Turkey), Grant number: 1059B191400255.

Hasta Onamı: Olgunun ölümü sebebiyle klinik takip devam etmediğinden onam alınamamıştır.

Hakem Değerlendirmesi: Dış bağımsız.

Yazar Katkıları: Fikir - M.Ş.E., A.Ö., O.K., O.E.B.; Tasarım - M.Ş.E., A.Ö.; Denetleme - A.Ö., T.B.; Kaynaklar - A.Ö., O.E.B., T.B.; Malzemeler - O.K., O.E.B., T.B.; Veri Toplanması ve/veya İşlemesi - A.Ö., M.Ş.E.; Analiz ve/ veya Yorum - M.Ş.E., A.Ö., O.E.B.; Literatür Taraması - M.Ş.E.; Yazıyı Yazan - O.E.B., M.Ş.E., A.Ö., O.K.; Eleştirel İnceleme - T.B.

Çıkar Çatışması: Yazarlar çıkar çatışması bildirmemişlerdir.

Finansal Destek: Murat Şakir Ekşi, MD Tübitak (Türkiye Bilimsel ve Teknolojik Araştırma Kurumu) bursu ile desteklenmiştir, Burs numarası: 1059B191400255.

\section{REFERENCES}

1. Moro P, Schantz PM. Echinococcosis: a review. Int J Infect Dis 2009; 13: 125-33. [CrossRef]
2. Tappe D, Kern P, Frosch M, Kern P. A hundred years of controversy about the taxonomic status of Echinococcus species. Acta Trop 2010; 115: 167-74. [CrossRef]

3. Thompson RC. Biology and systematics of Echinococcus. In: Thompson RC, Lymbery AJ, editors. Echinococcus and hydatid disease. London: CAB International; 1995. p. 1-37.

4. Wang X, Ding J, Guo X, Zheng Y. Current Understandings of Molecular Biology of Echinococcus multilocularis, a Pathogen for Alveolar Echinococcosis in Humans- a Narrative Review Article. Iran J Parasitol 2015; 10: 329-37.

5. El-Shamam O, Amer T, El-Atta MA. Magnetic resonance imaging of simple and infected hydatid cysts of the brain. Magn Reson Imaging 2001; 19: 965-74. [CrossRef]

6. Turgut M. Intracranial hydatidosis in Turkey: its clinical presentation, diagnostic studies, surgical management, and outcome. A review of 276 cases. Neurosurg Rev 2001; 24: 200-8. [CrossRef]

7. Bukte Y, Kemaloglu S, Nazaroglu H, Ozkan U, Ceviz A, Simsek M. Cerebral hydatid disease: CT and MR imaging findings. Swiss Med Wkly 2004; 134: 459-67.

8. Tuzun M, Altinors N, Arda IS, Hekimoglu B. Cerebral hydatid disease CT and MR findings. Clin Imaging 2002; 26: 353-7. [CrossRef]

9. Gana R, Skhissi M, Maaqili R, Bellakhdar F. Multiple infected cerebral hydatid cysts. J Clin Neurosci 2008; 15: 591-3. [CrossRef]

10. Al Zain TJ, Al-Witry SH, Khalili HM, Aboud SH, Al Zain FT, Jr. Multiple intracranial hydatidosis. Acta Neurochir (Wien) 2002; 144: 1179-85. [CrossRef]

11. Yaka U, Aras Y, Aydoseli A, Akcakaya MO, Sencer A, Imer M, et al. Primary multiple cerebral hydatid disease: still symptomatic despite pathologically confirmed death of the cyst. Turk Neurosurg 2013; 23: 505-8.

12. Cavusoglu H, Tuncer C, Ozdilmac A, Aydin Y. Multiple intracranial hydatid cysts in a boy. Turk Neurosurg 2009; 19: 203-7.

13. Iplikcioglu AC, Ozek MM, Ozer AF, Ozgen T. Periventricular hydatid cyst presenting with hemichorea. Childs Nerv Syst 1992; 8: 292-3. [CrossRef]

14. Kaya U, Ozden B, Turker K, Tarcan B. Intracranial hydatid cysts. Study of 17 cases. J Neurosurg 1975; 42: 580-4. [CrossRef]

15. Onal C, Unal F, Barlas O, Izgi N, Hepgul K, Turantan Ml, et al. Longterm follow-up and results of thirty pediatric intracranial hydatid cysts: half a century of experience in the Department of Neurosurgery of the School of Medicine at the University of Istanbul (1952-2001). Pediatr Neurosurg 2001; 35: 72-81. [CrossRef]

16. Aras $Y$, Sabancı PA, Boyalı $O$, Aydoseli $A$, Güllüoğlu $M$, Bilgiç $M B$, et al. Alveolar Echinococcosis with Cranial Metastasis: Case Report and Review of the Literature. Türk Nöroşir Derg 2014; 24: 298-305.

17. Nazaroglu H, Ozates M, Bilici A, Simsek M. Multilocular cerebral hydatid disease with extracalvarial extension. AJR Am J Roentgenol 1999; 172: 1455-6. [CrossRef]

18. Tuzun M, Hekimoglu B. Hydatid disease of the CNS: imaging features. AJR Am J Roentgenol 1998; 171: 1497-500. [CrossRef]

19. Shcherbakov AM. [Human echinococcosis: the role of histocompatibility antigens in realizing infestations and the characteristics of their course]. Med Parazitol (Mosk) 1993: 13-8. 